\title{
KERAJAAN ALLAH MENURUT INJIL-INJIL SINOPTIK
}

\author{
Robi Panggarra \\ robipanggarra@yahoo.co.id
}

\begin{abstract}
ABSTRAK
Sesuai dengan pokok masalah yang ada, maka yang menjadi tujuan dalam penulisan karya ilmiah ini adalah: Pertama, untuk menemukan atau mengetahui apakah terdapat perbedaan dan persamaan gagasan tentang Kerajaan Allah dalam Injil-injil Sinoptik.Kedua, untuk mengetahui apa saja yang termasuk dalam aspek soteriologi, ekklesiologi, dan moral-etis tentang Kerajaan Allah. Ketiga, untuk mengetahui apa peran Yesus dalam Kerajaan Allah tersebut.

Adapun kesimpulan karya tulis "Kerajaan Allah Menurut Injil-Injil Sinoptik" adalah: Pertama, Kerajaan Allah merupakan pemerintahan Allah yang telah memasuki zaman ini melalui kehadiran Yesus dan akan menjadi sempurna pada saat kedatangan-Nya untuk kedua kalinya. Kedua, Ungkapan Kerajaan Allah dan Kerajaan Sorga memiliki makna yang sama, tanpa ada maksud untuk membedakan kedua objek dari ungkapan tersebut. Ketiga, Sinoptik menegaskan bahwa Kerajaan Allah yang akan datang merupakan sesuatu yang rahasia dan tidak diketahui kepastian waktunya. Keempat, Ketiga Injil memiliki pandangan yang sama tentang dimensi waktu sekarang dan futuris tentang Kerajaan. Kelima, Kerajaan Allah yang dibicarakan dalam Injil-injil Sinoptik, tidak terlepas kaitannya dengan misi soteriologi Allah untuk menyelamatkan umat-Nya dari perbudakan dosa. Keenam, Kerajaan Allah bekerja melalui gereja sekarang ini untuk mengabarkan kabar baik tentang tindakan Allah dalam sejarah, meskipun gereja bukanlah Kerajaan Allah itu sendiri. Ketujuh, Kerajaan Allah mengharuskan pertobatan untuk menyambutnya, dimana pertobatan itu akan menghasilkan sebuah kehidupan berbeda dari sebelumnya, oleh karena adanya prinsip-prinsip etis dari Kerajaan Allah yang perlu dihidupi oleh warga Kerajaan tersebut. Kedelapan, Yesus adalah inti pembicaraan Injil, sedangkan inti pemberitaan Yesus adalah Kerajaan Allah.
\end{abstract}

Kata Kunci: Kerajaan Allah, Injil-Injil Sinoptik 


\section{PENDAHULUAN}

\section{Latar Belakang Masalah}

Berbicara mengenai topik Kerajaan Allah merupakan sesuatu yang selalu menarik, tetapi sekaligus merupakan sesuatu yang selalu menantang. Menarik untuk membicarakan hal ini, oleh karena orangorang Kristen bergumul dengan tema tersebut dalam kehidupan mereka. Disebut menantang, oleh karena tidak mudah untuk memahami tentang tulisan-tulisan Perjanjian Baru mengenai topik tersebut. Hal ini mengundang banyak perdebatan pendapat mengenai topik Kerajaan Allah. Eldon Ladd berkata bahwa "Tidak ada pengajaran lain dalam Perjanjian Baru yang diperdebatkan dengan begitu bersemangat seperti topik Kerajaan Allah ini." J Jadi, dapat dikatakan bahwa topik Kerajaan Allah adalah sesuatu yang senantiasa menarik untuk dikaji dan diselidiki.

Georgia Harkness dalam bukunya Understanding the Kingdom of God mengatakan bahwa "Jesus preached the kingdom of God. We preach Jesus. In him and through the power of his message the kingdom is available to us. But can we preach Jesus or even understand him without understanding God's kingly rule, the central note in all his preaching? ${ }^{2}$ Kutipan ini mempertegas tentang sulitnya untuk mengkhotbahkan Yesus atau memahami Yesus tanpa mengerti Kerajaan Allah sebagai pusat dari pemberitaan Yesus sendiri. Dengan demikian, maka pemahaman tentang Kerajaan Allah merupakan sesuatu yang sunguh-sungguh diperlukan.

Kerajaan Allah merupakan sebuah tema sentral Perjanjian Baru yang tidak selalu mudah untuk dijelaskan dalam kelas-kelas teologi; bahkan lebih dari pada itu, selalu menjadi bagian diskusi yang hangat dalam percakapan-percakapan kelas atau pun di antara para teolog. Hal tersebut mengindikasikan bahwa tema ini perlu diperhatikan secara serius dalam studi Perjanjian Baru, kapan pun dan di mana pun.

Kenyataan ini mendorong untuk selalu melakukan kajian-kajian mendalam terhadap bagian ini, sehingga dapat memberikan jawaban atas berbagai pertanyaan atau rasa ingin tahu terhadap seluruh bagian yang tercakup dalam lingkup pembicaraan tema Kerajaan Allah.

\section{Pokok Masalah}

Berdasarkan latar belakang yang telah diuraikan di atas, jelas bahwa pembahasan tentang topik Kerajaan Allah perlu dilakukan agar

\footnotetext{
${ }^{1}$ George Eldon Ladd, Injil Kerajaan (Malang: Gandum Mas, 1994), 7.

${ }^{2}$ Georgia Harkness, Understanding the Kingdom of God: Chapter 1.Where We Stand; diakses tanggal 25 Januari 2013;tersedia di http://www.religiononline.org/showchapter.asp?title $=577 \& C=737$, diakses tanggal 25 Januari 2013.
} 
dapat menjawab berbagai permasalahan yang muncul dalam diskusidiskusi teologi setiap waktu. Oleh karena itu, melalui tulisan ini penulis juga ingin mengamati dan merangkum beberapa hal sebagai pokok masalah yang ingin diteliti dalam paper ini, antara lain:

Pertama, apa perbedaan dan persamaan gagasan tentang "Kerajaan Allah" atau "Kerajaan Surga" dalam Injil-injil Sinoptik?

Kedua, apa saja yang dapat ditemukan tentang Kerajaan Allah dalam aspek Soteriologi, Ekklesiologi, dan moral-etis?

Ketiga, apa peran Yesus dalam Kerajaan Allah?

\section{Tujuan Penulisan}

Memperhatikan latar belakang masalah yang telah dipaparkan di atas, maka beberapa tujuan yang ingin dicapai dalam penulisan ini, adalah sebagai berikut:

Pertama, untuk menemukan atau mengetahui apakah terdapat perbedaan dan persamaan gagasan tentang Kerajaan Allah dalam Injilinjil Sinoptik.

Kedua, untuk mengetahui apa saja yang termasuk dalam aspek soteriologi, ekklesiologi, dan moral-etis tentang Kerajaan Allah. tersebut.

Ketiga, untuk mengetahui apa peran Yesus dalam Kerajaan Allah 


\section{TINJAUAN KERAJAAN ALLAH}

\section{Apa itu Kerajaan Allah?}

Sebelum membahas lebih jauh tentang Kerajaan Allah, penting untuk memahami apa yang dimaksud dengan Kerajaan Allah. Oleh sebab itu, berikut adalah beberapa pendapat ahli tentang bagaimana mereka memberi definisi terhadap Kerajaan Allah.

Pertama, Menurut Gordon Fee yang dikutip oleh oleh Glen dan David dalam buku Etika Kerajaan, Kerajaan Allah adalah "Suatu peristiwa masa depan sekaligus suatu realitas masa kini."”

Kedua, Menurut George Eldon Ladd,

Kerajaan Allah adalah pemerintahan tertinggi Allah, namun pemerintahan Allah terwujud dalam tahap yang berbeda-beda sepanjang sejarah penebusan. Oleh karena itu, manusia dapat masuk ke dalam wilayah pemerintahan Allah dalam beberapa tahap perwujudannya dan mengalami berkat-berkat pemerintahan-Nya itu dalam kadar yang berbeda-beda. Kerajaan Allah adalah zaman yang akan datang, yang lazim disebut Sorga. Waktu itu kita akan mengalami berkat-berkat pemerintahan-Nya dalam kepenuhan yang sempurna. Akan tetapi, kerajaan itu ada di sini saat ini dan dapat kita nikmati sebagian dari berkat-berkat pemerintahan Allah itu secara nyata. ${ }^{4}$

Ketiga, Menurut Albert Schweitzer yang dikutip oleh Eldon Ladd dalam bukunya Injil Kerajaan, "Kerajaan Allah sama sekali bukanlah suatu kenyataan rohani atau kenyataan yang ada sekarang; Kerajaan Allah seluruhnya merupakan kenyataan masa mendatang dan bersifat adikodrati." ${ }^{5}$ Keempat, Graeme Goldsworthy has summarized a definition of the Kingdom of God as "God's people in God's place under God's rule. Kelima, Menurut Donald Guthrie, Kerajaan Allah menunjuk kepada adanya hubungan antara masa sekarang dan masa yang akan datang. Perwujudan ini akan lengkap hanya dalam kerajaan yang akan datang, tetapi sudah diwakili pada masa sekarang di dalam jemaat.

Memperhatikan beberapa definisi di atas, jelas bahwa terdapat perbedaan di antara para ahli untuk memberi definisi terhadap Kerajaan

${ }^{3}$ Glen H. Stassen \& David P. Gushee, Etika Kerajaan: Mengikut Yesus Dalam Konteks Masa Kini (Surabaya: Momentum, 2008), 4.

${ }^{4}$ George Eldon Ladd, Idem, 24-25.

${ }^{5} \mathrm{Ibid}, 16$.

${ }^{6}$ Kingdom of God; diakses tanggal 27 Januari 2013;tersedia di http://www.theopedia.com/Kingdom_of_God

${ }^{7}$ Donald Guthrie, Teologi Perjanjian Baru 3 (Jakarta:BPK, 1993), 26. 
Allah. Ketika membaca Injil Sinoptik, terdapat banyak ayat yang juga berbicara secara berbeda mengenai hal tersebut. Akan tetapi, berdasarkan pendapat di atas dan cara Alkitab menjelaskan konsep Kerajaan Allah, maka Kerajaan Allah jelas merupakan pemerintahan Allah yang mana telah memasuki zaman ini melalui kehadiran Yesus dan akan menjadi sempurna pada saat kedatangan-Nya untuk kedua kalinya.

\section{Kerajaan Allah Dalam Injil Sinoptik}

Konsep pengajaran tentang Kerajaan Allah terbentang di dalam Kitab-kitab Perjanjian Baru, mulai dari Kitab Injil Matius sampai kepada Kitab Wahyu. Injil Sinoptik banyak membicarakan konsep tersebut dalam kaitannya dengan pengajaran-pengajaran Yesus tentang Kerajaan Allah, sedangkan Paulus dan penulis surat-surat yang lain juga banyak mengajarkannya sebagai doktrin yang penting untuk diketahui oleh gereja. Hal tersebut kembali menjadi tekanan yang kuat dalam Kitab Wahyu yang ditulis oleh Yohanes, dan sekaligus menutup kitab Perjanjian Baru. Akan tetapi, fokus yang ingin disorot dalam tulisan ini bukanlah keseluruhan konsep Kerajaan Allah dalam Perjanjian Baru, melainkan terbatas pada konsep atau gagasan-gagasan yang terdapat dalam Injil Sinoptik.

\section{Injil Matius}

Seruan pertama tentang Kerajaan Sorga atau Kerajaan Allah dalam Injil Matius dimulai oleh kehadiran Yohanes Pembaptis yang berkhotbah agar orang-orang Yahudi bertobat sebab Kerajaan Sorga $(\dot{\eta} \beta \alpha \sigma \iota \lambda \in \dot{L} \alpha \tau \hat{\omega} \nu$ oủp $\alpha \nu \omega \hat{\omega} \nu)^{8}$ sudah dekat (Matius 3:1-2). Sesudah penangkapan Yohanes Pembaptis, barulah Yesus tampil untuk pertama kalinya di Galilea dan berbicara hal serupa yang telah disampaikan oleh Yohanes: "Bertobatlah, sebab Kerajaan Sorga sudah dekat!" (Matius 4:12-17). Yesus kemudian terus mengajarkan tentang konsep Kerajaan Allah meskipun dalam Injil Matius hal tersebut kebanyakan menggunakan istilah Kerajaan Sorga. Hal ini merupakan ekspresi Matius sebagai seorang Yahudi yang menulis kitab ini guna menghindari pemakaian kata Allah yang baginya sangat kudus. Hal tersebut sejalan dengan pemikiran D.A. Carson yang mengatakan bahwa:

The kingdom of heaven is Matthew's customary expression for what other New

Testament writers preferred to call the 'kingdom of God'. Matthew was like many Jews of his day who would avoid using the word 'God'. They felt it was too

\footnotetext{
${ }^{8}$ Sutanto, 9.
} 
holy, too exalted; therefore euphemism like 'heaven' were adopted. In meaning. Kingdom of heaven is identical to kingdom of God. ${ }^{9}$

Itulah sebabnya dalam Injil Matius istilah Kerajaan Allah hanya dipakai 5 kali, sedangkan istilah Kerajaan Sorga dipakai sebanyak 32 kali. ${ }^{10}$ Namun, tidak perlu mempertentangkan kedua istilah tersebut, oleh karena pada dasarnya Matius menunjuk kepada satu hal yang sama yaitu Kerajaan Allah.

Menarik bahwa Yesus memberitakan Kerajaan Allah serta melenyapkan segala penyakit dan kelemahan (Matius 4:23; 9:35). Dengan demikian, Yesus sedang menunjukkan bahwa pengusiran setan dan penyembuhan penyakit juga merupakan bagian yang tidak terlepas dari berita Kerajaan Allah tersebut. Yesus sedang mengajarkan kerajaan itu, dan orang-orang Yahudi sedang mengalaminya, meskipun tidak secara penuh dan juga tidak sama dengan pemahaman umum bangsa Yahudi (pengharapan Mesias Yahudi) tentang kerajaan itu. Hal itu akan lebih jelas ketika membaca Matius 12:22-28, di mana Yesus menunjukkan bahwa Dia mengusir setan dengan kuasa Roh Allah dan hal itu berarti kehadiran Kerajaan Allah. George Eldon Ladd mengatakan bahwa "Matius pasal 12 dengan jelas menyatakan pengusiran roh-roh jahat sebagai pekerjaan Kerajaan Allah." "ll

Yesus juga mengajar murid-murid bahwa Kerajaan Allah yang Ia beritakan merupakan kerajaan yang sarat dengan nilai-nilai etis. Hal tersebut dikisahkan dalam Matius 5 tentang kelemah-lembutan dan kerendahan hati. Leon Morris menegaskan bahwa "Orang-orang yang mempunyai sifat-sifat itulah yang akan masuk ke dalam Kerajaan, 'miskin di hadapan Allah' (5:3), yang dianiaya (5:10), yang bersifat seperti anak-anak (18:1-4). ${ }^{12}$ Yesus bahkan menegaskan dalam Matius 5:20 bahwa mereka tidak akan masuk Sorga jika hidup keagamaan mereka tidak lebih benar dari pada orang-orang Farisi. Oleh sebab itu, tuntutan untuk bertobat merupakan sesuatu yang penting dalam hal ini. John Legg menjelaskan arti pertobatan ini bahwa "It expressed God's frequent summons to Israel to return to God, to abandon their rebellion and come back to covenant-obedience. In other words, it is equivalent to conversion, a radical change of hearts as well as mind, leading to a changed life."13 $\mathrm{Hal}$ ini memberi arti terhadap khotbah Yohanes Pembaptis agar orang-orang bertobat untuk

\footnotetext{
${ }^{9}$ D. A. Carson, The Sermon on the Mount (UK: The Paternoster Press, 2000), 13.

${ }^{10}$ David Iman Santoso, Theologi Matius: Intisari dan Aplikasinya (Malang: SAAT, 2009), 144 .

${ }^{11}$ Ladd, 55.

${ }^{12}$ Leon Morris, Teologi Perjanjian Baru (Malang: Gandum Mas, 2001), 174-175.

${ }^{13} \mathrm{John}$ Legg, The King and His Kingdom (New York: Evangelical Press, 2004), 41.
} 
menyambut Kerajaan Sorga yang sudah dekat. Ada hal lain yang penting untuk diperhatikan sehubungan dengan Kerajaan Allah yang diajarkan oleh Yesus. Yesus banyak mengajarkan konsep Kerajaan Allah dalam bentuk perumpamaan. Dalam Injil Matius setidaknya terdapat 14 perumpamaan yang Yesus ajarkan. Hal itu menarik perhatian muridmurid Yesus, sehingga suatu kali mereka bertanya kepada Yesus: "Mengapa Engkau berkata-kata kepada mereka dalam perumpamaan? (Matius 13:10). Jawaban Yesus kepada murid-murid itu merupakan sesuatu yang juga menarik. Dalam Matius 13:11, "Jawab Yesus: kepadamu diberi karunia untuk mengetahui rahasia Kerajaam Sorga, tetapi mereka tidak." Sehingga tidaklah mengherankan jika Yesus kemudian mengajarkan hal Kerajaan Allah melalui perumpamaan-perumpamaan. Leon Morris berkata: "Perumpamaan-perumpamaan menjadi suatu studi yang hidup dan menarik, dan menampilkan aspek-aspek penting dari Kerajaan." Oleh sebab itu, memahami setiap perumpamaan yang diajarkan oleh Yesus merupakan hal penting yang perlu dilakukan untuk mengerti tentang Kerajaan Allah.

Perumpamaan pertama yang muncul dalam Injil Matius adalah perumpamaan tentang seorang penabur yang ke luar untuk menabur benih (Matius 13:1-23). Ada benih yang jatuh di pinggir jalan, tanah yang berbatu, di tengah semak duri, dan di tanah yang baik. Dan arti perumpamaan itu dijelaskan sendiri oleh Yesus dalam ayat 19-23 bahwa "Kepada setiap orang yang mendengar firman tentang Kerajaan Sorga, tetapi tidak mengertinya, datanglah si jahat dan merampas yang ditaburkan dalam hati orang itu; itulah benih yang ditaburkan di pinggir jalan. Benih yang ditaburkan di tanah yang berbatu-batu ialah orang yang mendengar firman itu dan segera menerimanya dengan gembira. Tetapi ia tidak berakar dan tahan sebentar saja. Apabila datang penindasan atau penganiayaan karena firman itu, orang itupun segera murtad. Yang ditaburkan di tengah semak duri ialah orang yang mendengar firman itu, lalu kekuatiran dunia ini dan tipu daya kekayaan menghimpit firman itu sehingga tidak berbuah. Yang ditaburkan di tanah yang baik ialah orang yang mendengar firman itu dan mengerti, dan karena itu ia berbuah, ada yang seratus kali lipat, ada yang enam puluh kali lipat, ada yang tiga puluh kali lipat." Eldon Ladd menjelaskan rahasia Kerajaan Allah ini, sebagai berikut:

Kerajaan Allah sudah datang di antara manusia, namun manusia bisa menolaknya. Kerajaan itu tidak mengalami keberhasilan yang sama. Tidak semua orang mau menerimanya. ... Kerajaan Allah sedang bekerja di antara manusia, tetapi Allah tidak akan memaksa manusia

\footnotetext{
${ }^{14}$ Morris, 180.
} 
untuk tunduk kepada Kerajaan tersebut. Mereka harus menerima Kerajaan itu dengan rela hati dan dengan kehendak yang patuh. ${ }^{15}$

Jadi, jelas bahwa kehadiran Kerajaan Allah sudah dimulai sejak kehadiran Yesus. Akan tetapi, kehadirannya masih bersifat rahasia; di mana ia tidak hadir dalam kekuasaan penuh melainkan bekerja secara diam-diam dalam kehidupan setiap mereka yang secara terbuka menerimanya dalam kehidupan mereka.

Pertanyaan penting yang muncul tentang Kerajaan itu ialah tentang waktu kapan Kerajaan itu akan hadir dengan kuasa yang penuh yang akan ditandai dengan kedatangan Yesus yang kedua kali? Ini merupakan suatu pertanyaan yang tidak mudah untuk dijawab. Namun, Matius memberi rujukan yang baik dalam pasal 24-25. Murid-murid bertanya tentang waktu kedatangan Yesus yang kedua dan apakah tanda-tandanya? Yesus tidak menjawab tentang hari, bulan atau tahun, tetapi Yesus menjelaskan tentang tanda-tanda zaman yang perlu dikenali. Hal tersebut akan diawali dengan munculnya mesias palsu (ayat 5), adanya perang dan keributan antar bangsa ${ }^{16}$ (ayat 6-7), adanya penganiayaan (ayat 9), adanya kemurtadan (ayat 10), munculnya nabi palsu (ayat 11), menurunnya kualitas kasih (ayat 12), dan Injil akan disampaikan di seluruh dunia (ayat 14). Memperhatikan penjelasan Yesus tersebut, Matthew Henry berkata bahwa "Kita tidak perlu mengetahui masa dan waktu yang ditetapkan Bapa (Kis.l:7)." ${ }^{\text {,17 }}$ Tidak perlu mencoba melakukan perhitungan waktu yang tepat tentang kedatangan-Nya, melainkan cukup memperhatikan tanda-tanda zaman itu.

\section{Injil Markus}

Sebagaimana Matius, Markus juga menampilkan pelayanan awal Yesus di Galilea setelah penangkapan Yohanes, dengan seruan "Waktunya telah genap; Kerajaan Allah sudah dekat (Makus 1:14-15). Namun, hal yang menarik dalam cara Markus merumuskan pernyataannya, ialah adanya pernyataan "Waktunya telah genap." Samuel Benyamin Hakh berkomentar tentang ayat ini bahwa:

Jika kita memperhatikan rumusan kalimat itu dalam Injil Markus maka jelas bahwa rumusan itu disusun dalam bentuk kalimat perfek. Bentuk kalimat itu menandai suatu kontinuitas aksi yang terjadi pada waktu tertentu di masa lampau dan berlangsung terus

\footnotetext{
${ }^{15}$ Ladd, 67.

${ }^{16}$ Matthew Henry, Tafsiran Matthew Henry Injil Matius 15-28 (Surabaya: Momentum, 2008), 1220.

${ }^{17}$ Henry, 1213.
} 
hingga masa kini. Jadi Markus melihat ke masa lampau, kepada pelayanan Yesus di Galilea dan memahami bahwa dalam diri Yesus, Kerajaan Allah telah tiba. Namun ia menyadari bahwa Kerajaan itu telah berlangsung hingga masa kini. Dalam kaitan ini, Markus hendak menekankan suatu eskatologi yang telah mewujud sebagai kunci hermeneutik dalam teologinya. Sebab menurut Markus, dengan mulainya pelayanan Yesus di Galilea, waktu penggenapan itu telah tiba dan suatu permulaan baru sedang mulai. Permulaan baru itu adalah membelah masuknya Kerajaan Allah dalam sejarah manusia. $^{18}$

Dengan demikian, maka frase itu menjadi penting dalam catatan Markus dan sekaligus menjadikannya unik di antara kedua Injil Sinoptik yang lain dalam menjelaskan tentang Kerajaan Allah yang sudah hadir dalam diri Yesus.

Dikatakan bahwa Kerajaan Allah "sudah dekat." Kata ini dipakai baik oleh Markus, maupun Matius dan Lukas. Samuel Hakh menjelaskan bahwa:

Terjemahan ini lebih menggambarkan aspek present (ke-kini-an) dan futuris (ke-akan-an) dari Kerajaan itu. Jadi pada suatu pihak kata ini menggambarkan aspek ke-kini-an yakni kehadiran Kerajaan Allah secara tersembunyi pada masa kini pelayanan Yesus, tetapi pada pihak lain, mempertahankan aspek ke-akan-an dari Kerajaan itu. Pemenuhan Kerajaan Allah itu dengan kuasa masih ada di depan. Memang Kerajaan Allah telah datang dalam sejarah. Pemerintahan Allah telah berlaku dan waktu yang telah ditetapkan itu telah genap. Meskipun begitu pemenuhan secara sempurna itu belum tiba, pemenuhan itu masih ada di depan. ${ }^{19}$

Berdasarkan penjelasan di atas, Kerajaan Allah dilihat sebagai pemerintahan Allah yang sudah berlaku kini, meskipun memiliki aspek futuris dimana hal itu akan terwujud secara penuh di masa yang akan datang.

Dampak dari kehadiran Kerajaan Allah pada masa kini adalah bersifat rahasia bagi manusia. Namun, ada pertentangan yang nyata antara hadirnya Kerajaan Allah terhadap kerajaan dunia yang dikuasai oleh setan. Dalam hal ini, sedikit berbeda dengan Matius; Markus segera menempatkan cerita pelayanan Yesus sesudah pemilihan murid-murid

\footnotetext{
${ }^{18}$ Samuel Benyamin Hakh, Pemberitaan Tentang Yesus Menurut Injil-injil Sinoptik (Bandung: Jurnal Info Media, 2007), 24-25.

${ }^{99}$ Hakh, 25-26.
} 
yang juga dicatat oleh Matius. Markus 1:21-28 menceritakan bahwa Yesus berada dalam sebuah rumah ibadat di Kapernaum, dan di sana ada seorang yang kerasukan roh jahat. Ketika melihat Yesus, orang itu berteriak: Apa urusan-Mu dengan kami, hai Yesus orang Nazaret? Engkau datang hendak membinasakan kami? Aku tahu siapa Engkau yang Kudus dari Allah. Perikop tersebut secara jelas memperlihatkan bahwa kehadiran Yesus merupakan sebuah "benturan atau konflik"20 terhadap setan sebagai penguasa kerajaan dunia (Matius 4:8-9). Hal tersebut diulang dalam Markus 5:1-20, di mana Yesus kembali berjumpa dengan seorang yang dirasuk setan. Markus bercerita bahwa tidak seorang pun lagi yang sanggup mengikat orang itu, sekalipun dengan rantai karena rantai-rantai pun dimusnahkannya. Namun ketika ia bertemu dengan Yesus, ia berteriak dengan keras: Apa urusan-Mu dengan aku, hai Yesus, Anak Allah yang Mahatinggi? Demi Allah, jangan siksa aku! Catatan penting dari kedua cerita ini adalah bagaimana orang-orang yang dirasuk setan tersebut segera mengenali Yesus sebagai Anak Allah, dan bagaimana ketakutan mereka tentang tindakan penghukuman Yesus. Penguasa kerajaan dunia tidak berdaya terhadap kehadiran Yesus atau dengan kata lain tidak mampu melawan Kerajaan Allah. Ungkapan orang-orang yang kerasukan itu, memberi arti penting terhadap pelayanan Yesus sebagai tanda kehadiran Kerajaan Allah. Markus menekankan bahwa "Tidak ada seorang pun lagi yang sanggup mengikat" orang yang kerasukan di Gerasa itu. Akan tetapi, Yesus menundukkannya dengan begitu mudah, bahkan Markus mencatat bahwa roh jahat itu sendiri yang meminta untuk diizinkan berpindah dari dalam diri orang yang dirasuknya ke dalam babi-babi yang ada di sana. Yesus sudah datang, Kerajaan Allah sudah hadir, dan penguasa kerajaan dunia sudah diserang. Walaupun, kuasa Kerajaan Allah belum dinampakkan secara penuh.

Pengajaran tentang Kerajaan Allah melalui perumpamaanperumpamaan juga tidak luput dari perhatian Markus. Perumpamaan tentang seorang penabur yang juga dicatat dalam Injil Matius dan Lukas mengawali cerita perumpamaan dalam Injil ini. Akan tetapi, ada hal yang menarik yaitu perumpamaan tentang benih yang tumbuh. Cerita tersebut hanya dicatat oleh Markus (Markus 4:26-29). Kerajaan Allah digambarkan sebagai seorang yang menaburkan benih di tanah, lalu tidur pada malam hari dan bangun pada keesokan harinya, tetapi benih itu telah mengeluarkan tunas. Bagaimana tunas itu menjadi tinggi dan semakin tinggi, tidak diketahui oleh orang itu. Namun setelah berbuah, orang itu akan menyabit sebab musim menuai sudah tiba. Markus menjelaskan sesuatu yang berbeda dari Kerajaan Allah itu, yakni

\footnotetext{
${ }^{20}$ Ibid., 29.
} 
bagaimana ia tumbuh dan tidak diketahui. Kerajaan Allah adalah pekerjaan Allah sendiri, manusia tidak tahu bagaimana ia bertumbuh dan berbuah. Mengenai hal kedatangan Yesus yang kedua kali, hal tersebut dijelaskan Markus sebagaimana Matius dan Lukas. Markus memaparkan cerita apa adanya tentang perkataan-perkataan Yesus mengenai hari itu. Tidak tekanan tentang hari, bulan atau waktu tertentu, kecuali tanda-tanda zaman yang akan mendahului peristiwa tersebut.

\section{Injil Lukas}

Tiga pasal yang pertama dari Injil Lukas merupakan sejarah atau silsilah dan persiapan kelahiran serta pelayanan Yesus. Hanya Lukas yang menceritakan nubuatan kelahiran Yohanes Pembaptis, kunjungan Maria kepada Elisabet, pujian Maria, kelahiran Yohanes Pembaptis dan pujian Zakharia. Marshall menjelaskan hal ini bahwa:

At the outset Luke makes it clear that he is attempting to give an account of what actually happened based on reliable testimony and that he is doing so in order that his reader(s) may be sure that what they have been taught rests on a sound foundation. Already at this point we learn that Luke is concerned that the Christian message rests on historical events (Luke 1:1-4). ${ }^{21}$

Penekanan Lukas terhadap sejarah membuat adanya perbedaan pengutipan pengajaran Yesus tentang Kerajaan Allah dalam Markus 1:1415 dengan Lukas 4:14-15, dimana Lukas mengutip secara berbeda dengan yang Matius lakukan (Matius 4:12-17). Namun lebih lanjut Samuel Hakh menjelaskan bahwa hal itu tidak berarti Lukas mengabaikan pemberitaan tentang Kerajaan Allah sebagai pokok pemberitaan Yesus. Hal tersebut akan menjadi jelas, jika membaca Lukas 4:43; 8:1 dan 9:11. ${ }^{22}$ Lukas 4:43, Yesus berkata: "juga di kota-kota lain Aku harus memberitakan Injil Kerajaan Allah sebab untuk itulah Aku diutus." Demikian juga pasal 8:1 "Yesus berjalan berkeliling dari kota ke kota dan dari desa ke desa memberitakan Injil Kerajaan Allah. Sementara itu pasal 9:11 "Ia menerima mereka dan berkata-kata kepada mereka tentang Kerajaan Allah dan Ia menyembuhkan orang-orang yang memerlukan penyembuhan." "Lebih lanjut Tuhan Yesus menjelaskan bahwa siapa saja yang menerima pengajaran-Nya dan misi-Nya sudah masuk Kerajaan Allah pada saat ini (Lukas 16:16)." ${ }^{23}$ Dengan demikian, jelas bahwa

${ }^{21}$ I. Howard Marshall, New Testament Teology (USA: InterVarsity Press, 2004), 130.

${ }^{22} \mathrm{Hakh}, 53$.

${ }^{23}$ Ladd, 18. 
Lukas pun memberi perhatian tentang Kerajaan Allah; hanya saja berbeda dengan Matius dan Markus, Lukas lebih menekankan "aksi atau tindakan Allah dari pada pemberitaan tentang Kerajaan Allah itu sendiri. ${ }^{24}$ Akan tetapi, bagaimana pun Lukas juga sependapat bahwa Kerajaan Allah memiliki dimensi kekinian dan juga futuris yang akan terjadi di masa mendatang (Lukas 9:27 bnd Lukas 10:9).

Berdasarkan penjelasan Injil-injil Sinoptik di atas, dapat disimpulkan bahwa ketiga Injil memberikan perhatian yang serius terhadap Kerajaan Allah. Selain itu, ketiga Injil juga menampilkan bahwa Kerajaan Allah sudah dimulai melalui kehadiran Yesus. Yesus bukan hanya mengajarkan kerajaan itu, tetapi Yesus juga sudah mendemonstrasikan kehadiran kerajaan itu melalui pelayanan-Nya. Akan tetapi, meskipun Kerajaan Allah itu sudah datang dan memasuki dimensi waktu sekarang, namun Kerajaan Allah itu bekerja secara rahasia sampai kepada suatu masa di mana kerajaan tersebut akan tampil dalam kesempurnaannya di mana orang-orang percaya akan mengalami kepenuhan berkat Kerajaan itu.

\section{KERAJAAN ALLAH BERDASARKAN INJIL SINOPTIK}

Memperhatikan tinjauan Injil Sinoptik tentang Kerajaan Allah pada bab sebelumnya, maka ada beberapa hal penting yang perlu diperhatikan sehubungan dengan Kerajaan Allah. Mulai dari persamaan atau perbedaan konsep Kerajaan Allah dalam Injil Sinoptik, sampai kepada aspek-aspek Kerajaan Allah seperti: soteriologis, ekklesiologis, moral-etis, serta juga untuk melihat apa peran Yesus dalam Kerajaan Allah tersebut.

\section{Persamaan dan Perbedaan Gagasan Tentang Kerajaan Allah}

Matius, Markus, maupun Lukas sama-sama mencatat gagasan tentang Kerajaan Allah di dalam Injil mereka masing-masing. Terdapat begitu banyak ayat dalam kitab-kitab ini tentang gagasan Kerajaan Allah. Di antara banyaknya ayat-ayat tersebut, dapat ditemukan persamaan dan perbedaan gagasan mereka tentang Kerajaan Allah melalui ayat-ayat paralel.

Pertama, Di dalam Matius 4:12-17; Markus 1:14-15; Lukas 4:14-15, Matius dan Markus memiliki kesamaan dalam hal bagaimana Yesus mulai mengajarkan Kerajaan Allah lewat pemberitaan-Nya. Kedua penulis menampilkan pemberitaan Yesus untuk "bertobat karena Kerajaan Sorga sudah dekat", meskipun dengan gaya penulisan masingmasing. Matius hanya menekankan kata "bertobatlah", sementara

\footnotetext{
${ }^{24}$ Hakh, 53.
} 
Markus menambahkan kalimat "waktunya sudah genap" serta kata "percayalah kepada Injil. Marshall berkata bahwa: struktur dasar dari keduanya adalah sama, hanya saja tidak pantas jika Matius menggunakan bentuk kata-kata yang sama. ${ }^{25}$ Hal yang menarik adalah perbedaan cara Lukas dalam mengkalimatkan ayat ini: "Dalam kuasa Roh Allah kembalilah Yesus ke Galilea. Dan tersiarlah kabar tentang Dia di seluruh daerah itu. Sementara itu Ia mengajar di rumah-rumah ibadat di situ dan semua orang memuji Dia" (Lukas 4:14-15). Walaupun ayat ini sejajar dengan ungkapan Matius dan Markus, namun Lukas sama sekali tidak menggunakan kata "Kerajaan Allah" serta kata "bertobatlah". Lukas memberi tekanan pada tindakan Yesus untuk mengajar dan bahwa tersiar kabar tentang Dia. Dengan demikian Yesus mengsejajarkan antara berita "Kerajaan Allah" dengan kabar yang tersiar tentang diri-Nya. Untuk hal ini, Marshaal berpendapat bahwa:

I shall assume that Luke is telling his story of Jesus on the basis of Mark's Gospel together with other source materials, some shared with Matthew and others peculiar to himself. Therefore, the main thread of story is similar to that in Mark, and in many ways Luke shared his understanding of it. But like Matthew, Luke is writing at greater length than Mark, and the new material gives the Markan material to express different nuances. ${ }^{26}$

Jadi, jelas bahwa Lukas menyusun Injilnya serupa dengan Markus, hanya saja ada penambahan pemahaman Lukas secara pribadi untuk menekankan nuansa yang berbeda dari tulisannya tersebut.

Kedua, Penggunaan istilah "Kerajaan Allah" dalam Injil Matius dibandingkan dengan pemakaian istilah tersebut oleh Markus dan Lukas. Jika Markus dan Lukas konsisten menggunakan frase tersebut, sebaliknya Matius menggantinya dengan istilah "Kerajaan Sorga" (Matius 4:17 bnd Markus 1:15). "Istilah Kerajaan Allah dan Kerajaan Sorga mempunyai arti yang sama." ${ }^{27}$ Matius lebih manyukai pemakaian Kerajaan Sorga dari pada Kerajaan Allah. Leon Morris menulis bahwa Matius hanya lima kali memakai ungkapan Kerajaan Allah, sedangkan ungkapan Kerajaan Sorga dipakai 32 kali. Hal ini dilakukannya sebagai cara khas orang Yahudi menghindari penggunaan nama Allah. ${ }^{28} \mathrm{Jika}$ demikian maka perbedaan kedua istilah tersebut muncul bukan karena makna yang ingin disampaikan, melainkan lebih kepada latar belakang ke-Yahudian Matius sebagai panulis. Kedua istilah tersebut menunjuk

\footnotetext{
${ }^{25}$ I. Howard Marshall, New Testament Teology (USA: InterVarsity Press, 2004), 96.

${ }^{26} \mathrm{Ibid}, 129-130$.

${ }^{27}$ Marulak Pasaribu, Eksposisi Injil Sinoptik (Malang: Gandum Mas, 2005), 149.

${ }^{28}$ Morris, 174.
} 
kepada kerjaan yang sama dan tidak ada maksud untuk membedakan adanya dua Kerajaan yang berbeda di antara kedua istilah tersebut.

Ketiga, jika membaca Matius 12:28 dan Lukas 11:20, ada tekanan bahwa "jika Aku mengusir setan dengan kuasa (Roh) Allah, maka sesungguhnya Kerajaan Allah sudah datang kepadamu." Markus menggunakan istilah lain yaitu "sudahlah tiba kesudahannya" (Markus 3:26). Ungkapan ketiga Injil tersebut sama-sama menyorot kepada realitas kehadiran Kerajaan Allah yang masuk ke dalam sejarah umat manusia pada masa kini. George Eldon Ladd berkata: "Tindakan pengusiran roh-roh jahat membuktikan bahwa Kerajaan Allah sudah datang dan sedang bekerja di antara umat manusia. Pengusiran roh jahat itu sendiri merupakan pekerjaan Kerajaan Allah., ${ }^{29}$ Tekanannya jelas bahwa ketika terjadi penyerangan dan pengusiran roh jahat, maka pada saat itu Kerajaan Allah telah hadir dan sedang bekerja.

Keempat, meskipun di atas dijelaskan mengenai Kerajaan Allah yang sudah datang ke dalam dimensi sejarah manusia, namun ketiga Injil juga menulis tentang kedatangan Yesus pada masa yang akan datang sebagai bagian penting dalam pemenuhan janji berkat Kerajaan Allah secara sempurna (Matius 24; Markus 13; Lukas 21). Selain itu, ada juga beberapa ungkapan Yesus yang memberi kesan terhadap masa yang akan datang tersebut. Eldon Ladd mengutip Matius 12:32 dikatakan, "Apabila seorang mengatakan sesuatu menentang Anak Manusia, ia akan diampuni, tetapi jika ia menentang Roh Kudus, ia tidak akan diampuni, di dunia ini tidak, dan di dunia yang akan datang pun tidak". Lalu Eldon Ladd menjelaskan menjelaskan bahwa keseluruhan batas hidup manusia digambarkan dalam kaitannya dengan zaman ini dan zaman yang akan datang. ${ }^{30}$ Tidak ada keraguan akan masa yang akan datang tersebut, oleh karena Yesus sendiri pun memberikan indikasi-indikasi tentang hal itu dalam ucapan-Nya (Markus 10:29-30). Frank Thielman menulis bahwa:

Christianity has traditionally affirmed that with the coming of Jesus the biblical promises about the restoration of creation and of God's people have largely been fulfilled but the elements of fulfillment await the future. There is nothing incoherent about affirming both that God has "already" begun to fulfill His promises for the future in Jesus and that this fulfillment is "not yet" complete. $^{31}$

Jadi, apa yang dikemukakan oleh ketiga Injil tentang Kerajaan Allah pada zaman yang akan datang merupakan suatu kebenaran yang

\footnotetext{
${ }^{29}$ Ladd, 56.

${ }^{30}$ Ibid., 29.

${ }^{31}$ Frank Thielman, Theology of the New Testament (Michigan: Zondervan, 2005), 176.
} 
tidak perlu diragukan. Zaman itu belum dapat dikatakan lengkap sekarang ini, sampai pada waktu yang ditentukan di masa yang akan datang tersebut.

\section{Aspek Soteriologis Kerajaan Allah}

Dalam Injil Sinoptik, berita Kerajaan Allah dikaitkan langsung dengan kata perintah "bertobatlah" (Matius 4:17; Markus 1:15). Bahkan jika melihat catatan Markus, selain perintah bertobat ada juga perintah "percayalah". Seruan tersebut merupakan peringatan tajam terhadap datangnya sesuatu yang baru dan sekaligus merupakan kebutuhan dasar manusia. Manusia yang hidup dalam dosa dan perlu penebusan, sebagaimana yang ditulis oleh Matius (Matius 1:21). Di sisi lain, Kerajaan Allah itu juga hadir dengan penyerangan terhadap kerajaan setan. Eldon Ladd berkata "Kerajaan Allah adalah tindakan penaklukan yang Allah lakukan terhadap musuh-musuh-Nya: dosa, iblis dan maut, melalui Kristus." ${ }^{32}$ Memperhatikan tulisan Matius tentang "Yesus yang akan menyelamatkan umat-Nya dari dosa" dan catatan Eldon Ladd tentang penaklukan Kerajaan Allah yang dilakukan melalui Yesus, maka dapat dipahami bahwa Kerajaan Allah hadir dan membawa penyelamatan kepada umat Allah. Ini adalah sebuah kabar sukacita, bahwa manusia yang berdosa dan berada di bawah kuasa dosa, maut dan Iblis, akhirnya menemukan solusi atas persoalan itu. Solusi itu bukanlah sebuah usaha manusia, melainkan sebuah pemberian Allah melalui Kristus. Kerajaan Allah hadir bukan hanya sekedar memerangi dan menaklukkan kerajaan setan, tetapi sekaligus merampas atau menyelematkan umat kepunyaan-Nya yang menjadi tawanan setan melalui dosa untuk menjadi warga Kerajaan-Nya. Howard Marshall menegaskan bahwa: "His role has to do with saving people from sin." ${ }^{33}$ Selain itu, Howard Mashall juga menulis bahwa: "Traditionally Jesus is understood to go on to prophesy the coming of the Son of Man to gather together His disciples scattered all over the world, presumably in to God's new world, the future manifestation of the Kingdom of God." ${ }^{34}$

Jadi bagaimanapun, Kerajaan Allah yang dibicarakan dalam Injilinjil Sinoptik, tidak terlepas kaitannya dengan misi soteriologi Allah untuk menyelamatkan umat-Nya dari perbudakan dosa. Walaupun manusia masih hidup di dunia ini, namun keselamatan dari dosa telah ditawarkan oleh Allah melalui Yesus. Yesus telah menyelesaikan tugasNya untuk masalah dosa, akan tetapi hal itu akan terwujud secara penuh

\footnotetext{
${ }^{32}$ Ladd, 115.

${ }^{33}$ Marshall, 97.

${ }^{34}$ Ibid., 87.
} 
pada kedatangan-Nya yang kedua kali untuk menjemput manusia, yakni mereka yang telah diselamatkan melalui pengorbanan-Nya sendiri.

\section{Aspek Ekklesiologis Kerajaan Allah}

Ada hal yang menarik dalam mebaca Kitab-kitab Injil Sinoptik dalam hubungan dengan Ekklesia. Hal itu disebabkan oleh karena kata Ekklesia hanya muncul dalam Kitab Injil Matius (Matius 16:18 dst; 18:1718). ${ }^{35}$ Akan tetapi sekalipun demikian, tidak berarti bahwa gagasangagasan mengenai jemaat/gereja tidak terdapat dalam Injil-injil Sinoptik. Catatan Eldon Ladd dalam bukunya Injil Kerajaan memberikan penjelasan tentang hal tersebut, bahwa sejak awal Kerajaan Allah ditawarkan kepada Bangsa Israel (Matius 10:6). Yesus menegaskan bahwa Ia datang untuk domba-domba yang hilang dari umat Israel (Matius 15:24). Mereka disebut sebagai "anak-anak Kerajaan" (Matius 8:12), walaupun mereka tidak percaya dan menolak Mesias. Kerajaan ini menjadi milik mereka berdasarkan pemilihan Allah, sejarah dan warisan. Tetapi karena mereka menolak, maka Allah memberikan berkat-berkat itu kepada orang lain yang mau menerimanya. Hal tersebut melahirkan gagasan mengenai maksud Yesus untuk membangun atau mendirikan jemaat-Nya (ekklesia) dalam Matius 16:18. Hal ini dipahami oleh Eldon Ladd sebagai tujuan Yesus untuk membangun suatu jemaat yang baru, oleh karena penolakan Israel. Sebagai pemerintahan Allah dan tindakan Allah yang melakukan penebusan melalui Kristus, Kerajaan Allah menciptakan gereja dan kemudian bekerja melalui gereja di dunia ini. Oleh sebab itu, dengan cara yang sama Kerajaan Allah yaitu kegiatan dan kuasa Allah yang mendatangkan keselamatan, sedang bekerja di dunia pada saat ini sebagai Gereja Yesus Kristus. Gereja merupakan persekutuan murid-murid yang telah menerima kehidupan kerajaan dan mempunyai kesetian untuk mengabarkan berita Injil Kerajaan di dunia ini. Demikianlah Eldon Ladd melihat gereja sebagai bagian dari tujuan awal Yesus untuk membangun Kerajaan Allah. Gereja adalah umat Allah, namun bukan Kerajaan Allah. Kerajaan Allah menciptakan gereja dan bekerja di dunia melalui gereja. Hal ini penting untuk memahami bahwa manusia tidak dapat mendirikan Kerajaan Allah, tetapi mereka dapat memberitakan mengenai kerajaan itu. Kerajaan Allah yang dalam Perjanjian Lama diwujudkan melalui Israel, sekarang sedang bekerja di dunia melalui gereja. ${ }^{36}$

Dengan demikian, jelas bahwa gereja sendiri bukanlah Kerajaan Allah, melainkan hanya bersifat komunitas yang menjadi alat dalam mewujudkan berkat-berkat Kerajaan Allah di dunia sekarang ini,

\footnotetext{
${ }^{35}$ Guthrie, 22.

${ }^{36}$ Ladd, 131-143.
} 
termasuk dalam hal pergumulan melawan kejahatan sampai pada waktu dimana Kristus sendiri akan datang membawa pemerintahan Kerajaan Allah secara sempurna. Hal ini menjelaskan peranan gereja sebagai alat Kerajaan Allah yang harus aktif dalam mengabarkan berita Kerajaan Allah yang secara penuh akan dinyatakan pada masa yang akan datang.

\section{Aspek Moral-Etis Kerajaan Allah}

Sebagaimana telah dijelaskan tentang kehadiran Kerajaan Allah di dunia yang sekarang ini bekerja melalui gereja, maka ada persoalan baru yang penting untuk diperhatikan, yaitu moral-etis. Samuel Hakh mengatakan: "Hadirnya Kerajaan Sorga sebagai suatu realitas dalam kehidupan manusia memiliki dimensi etis bagi setiap orang yang bertemu dengan kerajaan itu." ${ }^{37}$ Tidak dapat dihindari bahwa Kerajaan Allah memilih nilai-nilai etis yang mengatur cara hidup warga kerajaan tersebut. Hal tersebut melahirkan pilihan untuk hidup sebagai warga Kerajaan Allah atau menolak untuk menerima sehingga terbebas dari tuntutan tersebut.

Tekanan terhadap aspek moral-etis ini, dibicarakan dalam Injil Sinoptik melalui pengajaran Yesus dalam khotbah di bukit (Matius 5; Lukas 6). Matius 5:20 mengatakan: "Maka Aku berkata kepadamu: Jika hidup keagamaanmu tidak lebih benar dari pada hidup keagamaan ahliahli Taurat dan orang-orang Farisi, sesungguhnya kamu tidak akan masuk ke dalam Kerajaan Sorga." Jelas bahwa hal ini merupakan syarat untuk masuk ke dalam Kerajaan Sorga. Sebabnya, perlu pengambilan keputusan untuk menerima Kerajaan tersbut. Eldon Ladd membenarkan pendapat Bulmann bahwa hal tersebut memberi makna tersendiri terhadap seruan Yesus "Bertobatlah, sebab Kerajaan Sorga sudah dekat." Di mana arti dasar dari dari kata "bertobat" adalah berbalik, mengubah jalan hidup, mengubah seluruh arah bertindak, berbalik dan mengikuti keputusan Kerajaan Allah. $^{38}$ Jadi, menerima Kerajaan Allah akan membawa kepada suatu kehidupan yang mengikuti aturan kerajaan tersebut.

Prinsip tersebut dijelaskan dalam Matius 5, di mana ungkapan bahagia tersebut diberikan kepada mereka yang termasuk dalam warga Kerajaan Allah. John Legg menegaskan hal itu bahwa "The beatitudes simply describe the character and characteristic of those who are blessed already, who belong to God's kingdom. ... The natural man cannot live as the beatitudes describe." ${ }^{39}$ Jadi, khotbah di bukit harus dipahami sebagai nilai-nilai moral-etis Kerajaan Allah yang perlu dihidupi oleh

\footnotetext{
${ }^{37}$ Hakh, 49.

${ }^{38}$ Ladd, 117.

${ }^{39}$ Legg, 58.
} 
setiap mereka yang telah menerima Yesus sebagai Mesias, dan dengan demikian menjadi warga Kerajaan Allah.

\section{Peranan Yesus Dalam Kerajaan Allah}

Ketika membaca Injil-injil Sinoptik, jelas bahwa berita tentang Kerajaan Allah dikaitkan dengan datangnya Sang Mesias yang akan membawa kemenangan kerajaan itu (Matius 12:28; Markus 1:15). Howard Marshall melihat bahwa:

The main theme of the Gospel is the identity of Jesus in His relationship to the kingdom of God. Mark spells this out in two stages. There is first the recognation of Jesus as Messiah and Son of God, with the evidence of the presence of the kingdom in and through the mighty works and His proclamation. Then there is the recognation that the Messiah must suffer and be raised from the dead, with the implications that this has for His followers. ${ }^{40}$

Kutipan di atas menunjukkan hubungan Yesus dengan Kerajaan Allah. Ia menampilkan Kerajaan Allah, mengerjakan Kerajaan Allah dan memprolamirkan kerajaan itu (Lukas 4:43; 11:20). Seruan bertobat merupakan peringatan tegas bahwa Kerajaan itu akan terwujud di dalam Yesus sebagai Mesias. Walaupun kemudian terdapat dua zaman yang berbeda dalam hal tersebut, namun semua catatan Sinoptik sepakat bahwa Kerajaan Allah telah memasuki dimensi waktu sekarang dengan kedatangan Yesus dan akan terwujud secara penuh pada dimensi waktu yang akan datang melalui kedatangan Yesus pula untuk kedua kalinya.

Selain itu, Yesus juga telah membangun suatu umat yang baru yang dimulai dari murid-murid-Nya sampai kepada masa di mana gereja telah muncul sebagai persekutuan orang-orang yang menerima-Nya, sebagai akibat dari penolakan Israel. Yesus kemudian menjelaskan inti misi dari kehadiran gereja untuk memberitakan Injil, dan pada akhirnya Yesus akan datang untuk menggenapi secara sempurna pemerintahan Kerajaan Allah, dimana pada waktu itu Iblis, dosa dan maut akan dimusnahkan. ${ }^{41}$ Jadi, Yesus akan menggenapkan seluruh nubuatan tentang Kerajaan Allah, mulai dari kehadiran Kerajaan Allah melalui kedatangan-Nya, misi Kerajaan Allah yang telah dikerjakan-Nya dan kemudian diteruskan kepada murid-murid-Nya (pada akhirnya menjadi tanggung jawab gereja), dan menghadirkan Kerajaan itu secara sempurna setelah kedatangan-Nya yang kedua kali pada masa yang akan datang.

\footnotetext{
40 Marshall, 91.

41 Ladd, 151.
} 


\section{PENUTUP}

\section{Kesimpulan}

Memperhatikan seluruh pembahasan pada bab-bab sebelumnya, maka ada beberapa kesimpulan tentang Kerajaan Allah dalam Injil Sinoptik. Kesimpulan-kesimpulan tersebut, antara lain:

Pertama, Kerajaan Allah merupakan pemerintahan Allah yang telah memasuki zaman ini melalui kehadiran Yesus dan akan menjadi sempurna pada saat kedatangan-Nya untuk kedua kalinya.

Kedua, Ungkapan Kerajaan Allah dan Kerajaan Sorga memiliki makna yang sama, tanpa ada maksud untuk membedakan kedua objek dari ungkapan tersebut. Pemakaian Kerajaan Sorga oleh Matius lebih kepada latar belakang ke-Yahudia-an Matius, untuk menghindari pemakaian nama Allah.

Ketiga, Sinoptik menegaskan bahwa Kerajaan Allah yang akan datang merupakan sesuatu yang rahasia dan tidak diketahui kepastian waktunya. Hanya saja ada tanda-tanda zaman yang dapat dikenali sebagai tanda kedatangan Yesus yang kedua kali.

Keempat, Ketiga Injil memiliki pandangan yang sama tentang dimensi waktu sekarang dan futuris tentang Kerajaan.

Kelima, Kerajaan Allah yang dibicarakan dalam Injil-injil Sinoptik, tidak terlepas kaitannya dengan misi soteriologi Allah untuk menyelamatkan umat-Nya dari perbudakan dosa. Kerajaan Allah telah membawa kemenangan atas roh jahat, dosa, serta mendatangkan keselamatan bagi mereka yang membuka hati terhadap pemberitaan kerajaan itu.

Keenam, Kerajaan Allah bekerja melalui gereja sekarang ini untuk mengabarkan kabar baik tentang tindakan Allah dalam sejarah, meskipun gereja bukanlah Kerajaan Allah itu sendiri. Manusia tidak dapat membangun Kerajaan Allah, melainkan Yesuslah yang akan membawa kerajaan itu secara sempurna pada masa depan yang akan datang.

Ketujuh, Kerajaan Allah mengharuskan pertobatan untuk menyambutnya, dimana pertobatan itu akan menghasilkan sebuah kehidupan berbeda dari sebelumnya, oleh karena adanya prinsip-prinsip etis dari Kerajaan Allah yang perlu dihidupi oleh warga Kerajaan tersebut.

Kedelapan, Yesus adalah inti pembicaraan Injil, sedangkan inti pemberitaan Yesus adalah Kerajaan Allah. Kerajaan Allah hadir melalui diri-Nya dan akan hadir secara sempurna dalam pemerintahan-Nya pada waktu kedatangan Yesus yang kedua kali di waktu yang akan datang. 


\title{
KEPUSTAKAAN
}

\author{
Buku-buku
}

Carson, D. A. The Sermon on the Mount. UK: The Paternoster Press, 2000.

Guthrie, Donald. Teologi Perjanjian Baru 3. Jakarta: BPK, 1993.

Hakh, Samuel Benyamin. Pemberitaan Tentang Yesus Menurut Injil-injil Sinoptik. Bandung: Jurnal Info Media, 2007.

Henry, Matthew. Tafsiran Matthew Henry Injil Matius 15-28. Surabaya: Momentum, 2008.

Ladd, George Eldon. Injil Kerajaan. Malang: Gandum Mas.

Legg, John. The King and His Kingdom. New York: Evangelical Press, 2004.

Marshall, I. Howard. New Testament Teology. USA: InterVarsity Press, 2004.

Morris, Leon. Teologi Perjanjian Baru. Malang: Gandum Mas, 2001.

Pasaribu, Marulak. Eksposisi Injil Sinoptik. Malang: Gandum Mas, 2005.

Santoso, David Iman. Theologi Matius: Intisari dan Aplikasinya. Malang: SAAT, 2009.

Stassen, Glen H. \& David P. Gushee, Etika Kerajaan: Mengikut Yesus Dalam Konteks Masa Kini. Surabaya: Momentum, 2008.

Sutanto, Hasan. Perjanjian Baru Interlinear Yunani-Indonesia dan Konkordansi Perjanjian Baru. Jakarta: LAI, 2004.

Thielman, Frank. Theology of the New Testament. Michigan: Zondervan, 2005.

\section{Bahan Internet}

Harkness, Georgia. Understanding the Kingdom of God: Chapter 1.Where We Stand;diakses tanggal 25 Januari 2013; tersedia di http://www.religiononline.org/showchapter.asp?title=577\&C=737 . Kingdom of God; diakses tanggal 27 Januari 2013;tersedia di http://www.theopedia.com/Kingdom_of_God, 